\title{
Bioengineered Skin Substitutes: Advances and Future Trends
}

\author{
Shima Tavakoli ${ }^{1}$ (D) and Agnes S. Klar ${ }^{2,3, *}$ \\ 1 Department of Materials Engineering, Isfahan University of Technology, Isfahan 84156-83111, Iran; \\ shimatavakoli1995@gmail.com \\ 2 Tissue Biology Research Unit, University Children's Hospital Zurich, University of Zurich, \\ 8952 Schlieren, Switzerland \\ 3 Children's Research Center, University Children's Hospital Zurich, 8032 Zurich, Switzerland \\ * Correspondence: AgnesSilvia.Klar@kispi.uzh.ch; Tel.: +41-44-6348-819
}

check for updates

Citation: Tavakoli, S.; Klar, A.S. Bioengineered Skin Substitutes: Advances and Future Trends. Appl. Sci. 2021, 11, 1493. https://doi.org/ 10.3390/app11041493

Academic Editor: Rossella Bedini Received: 6 December 2020

Accepted: 28 January 2021

Published: 7 February 2021

Publisher's Note: MDPI stays neutral with regard to jurisdictional claims in published maps and institutional affiliations.

Copyright: (c) 2021 by the authors. Licensee MDPI, Basel, Switzerland. This article is an open access article distributed under the terms and conditions of the Creative Commons Attribution (CC BY) license (https:/ / creativecommons.org/licenses/by/ $4.0 /)$.

\begin{abstract}
As the largest organ in the human body, the skin has the function of maintaining balance and protecting from external factors such as bacteria, chemicals, and temperature. If the wound does not heal in time after skin damage, it may cause infection or life-threatening complications. In particular, medical treatment of large skin defects caused by burns or trauma remains challenging. Therefore, human bioengineered skin substitutes represent an alternative approach to treat such injuries. Based on the chemical composition and scaffold material, skin substitutes can be classified into acellular or cellular grafts, as well as natural-based or synthetic skin substitutes. Further, they can be categorized as epidermal, dermal, and composite grafts, based on the skin component they contain. This review presents the common commercially available skin substitutes and their clinical use. Moreover, the choice of an appropriate hydrogel type to prepare cell-laden skin substitutes is discussed. Additionally, we present recent advances in the field of bioengineered human skin substitutes using three-dimensional (3D) bioprinting techniques. Finally, we discuss different skin substitute developments to meet different criteria for optimal wound healing.
\end{abstract}

Keywords: bioengineered skin; skin substitute; hydrogel scaffolds; 3D bioprinting

\section{Introduction}

Skin is the largest organ and protects the human body against the external environment [1]. Loss of the integrity of the skin barrier, as a result of injury or malformation may lead to major complications or even death. Therefore, wound healing represents a crucial ability of the human skin to repair any skin defect and to keep proper skin homeostasis.

Large and deep skin wounds caused by extensive burns or tissue trauma still pose a significant challenge for the surgeon. If those wounds do not heal in time after skin damage, they might cause infection or life-threatening complications. [2]. Therefore, it is pivotal to develop tissue-regenerating biomaterials with high biological activity. Accordingly, the ideal skin substitute should have good biocompatibility, antibacterial activity, proper hydrophilicity, and biodegradability [3].

In this review, we present commercially available skin substitutes for different clinical applications. Further, we demonstrate various treatment opportunities for skin defects and discuss their advantages and disadvantages to achieve optimal wound healing outcomes.

Moreover, we highlight the recent application of 3D bioprinting technologies to generate cell-based skin substitutes.

\section{Skin Injuries and Common Treatment Techniques}

The human skin consists of three major components including a superficial epidermis, a dermis, and a hypodermis [4]. The epidermis is composed of several layers. The outermost layer contains dead cells, which shed periodically and are continually replaced by cells derived from the basal layer [5]. The dermis connects the epidermis to the hypodermis 
layer, and due to the high content of collagen and elastin fibers, the dermis gives skin its strength and elasticity [6]. The hypodermis is the deepest layer of the skin located underneath the dermis. The hypodermis consists mainly of adipocytes, which accumulate fat. It also plays a role in thermoregulation, protection and provides insulation and cushioning for the integument [7].

The integrity of skin can be disrupted by various factors, leading to different types of wounds including acute and chronic wounds. Furthermore, wounds can be further split into mechanical injuries such as those caused by external factors (abrasions and tears) and skin injuries raised from radiation, electricity, corrosive chemicals, and thermal sources causing severe burns [8].

Skin wound healing is a complex, multi-stage process, which can be divided into homeostasis, inflammation, proliferation, and remodeling (maturation) phases [1]. To facilitate skin repair, the fine-tuned activation of numerous cell types such as keratinocytes, fibroblasts, endothelial cells, and immune cells is required. Furthermore, these cells secrete a variety of proinflammatory mediators, growth factors, and cytokines that promote skin repair [2]. Among immune cells, macrophages appear to be pivotal in this process [9-11]. They appear early during wound healing as so-called M1-polarized macrophages and differentiate to M2-phenotype at later stages of skin wound healing $[12,13]$. The phenotype change from M1 to M2 seems to be crucial to support the appropriate wound healing process. In contrast, prolonged M1-macrophage persistence in the wound might results in enhanced inflammation, leading to excessive scarring and delayed wound healing [11,14].

The human body is capable of healing minor superficial skin injuries by epithelialization without any particular treatment. However, large and deep skin defects require skin substitution to heal properly [15].

In particular, non-healing chronic wounds impose an immense financial burden on the healthcare systems and societies [2]. The primary reason for the impaired healing of chronic wounds is repeated tissue insults or accompanying diseases such as diabetes [16]. Moreover, in hard-to-heal chronic wounds, impaired vascularization is the main cause of delayed healing that might lead to tissue necrosis and, eventually, amputation [13,17]. In fact, capillaries are responsible for the metabolic exchange between blood and tissues $[18,19]$. If the angiogenesis process is disturbed, the wound cannot heal properly and the healing period is prolonged $[18,19]$. Thus, rapid neovascularization within only days after skin substitute implantation is of vital importance for the efficient healing of those wounds $[12,13,18,20-23]$.

\section{Cell-Based Skin Substitutes}

Chronic wounds influence a patient's life quality, leading to impaired mobility, sleep disturbance, psychological stress, and chronic pain [24]. A central problem causing poor skin wound healing in chronic wounds is impaired vascularization and cell activity [25]. Therefore, progress in the tissue engineering field aims for the development of cell-based wound substitutes or wound coverages that improve wound healing by promoting cell migration, differentiation, and vascularization [24]. The majority of cell-based skin substitutes are comprised of a scaffold upon which cells are seeded/cultured. Scaffolds are designed to integrate into the host tissue and provide an appropriate environment for cell growth, infiltration, and differentiation [26]. Thus, those scaffolds need to exhibit some specific characteristics such as appropriate porosity distribution to deliver oxygen and nutrients to cells and drive out carbon dioxide and waste products to allow cell proliferation, and expansion and biocompatibility. Moreover, the scaffold should mimic the mechanical properties of native human skin, which has an elastic modulus in the range of 88-300 kPa [27]. Accordingly, different skin templates have been engineered worldwide and there are various commercial cell-based templates for wound healing applications. Figure 1 demonstrates a classification and summary of commercial skin substitutes with examples discussed in this review. 


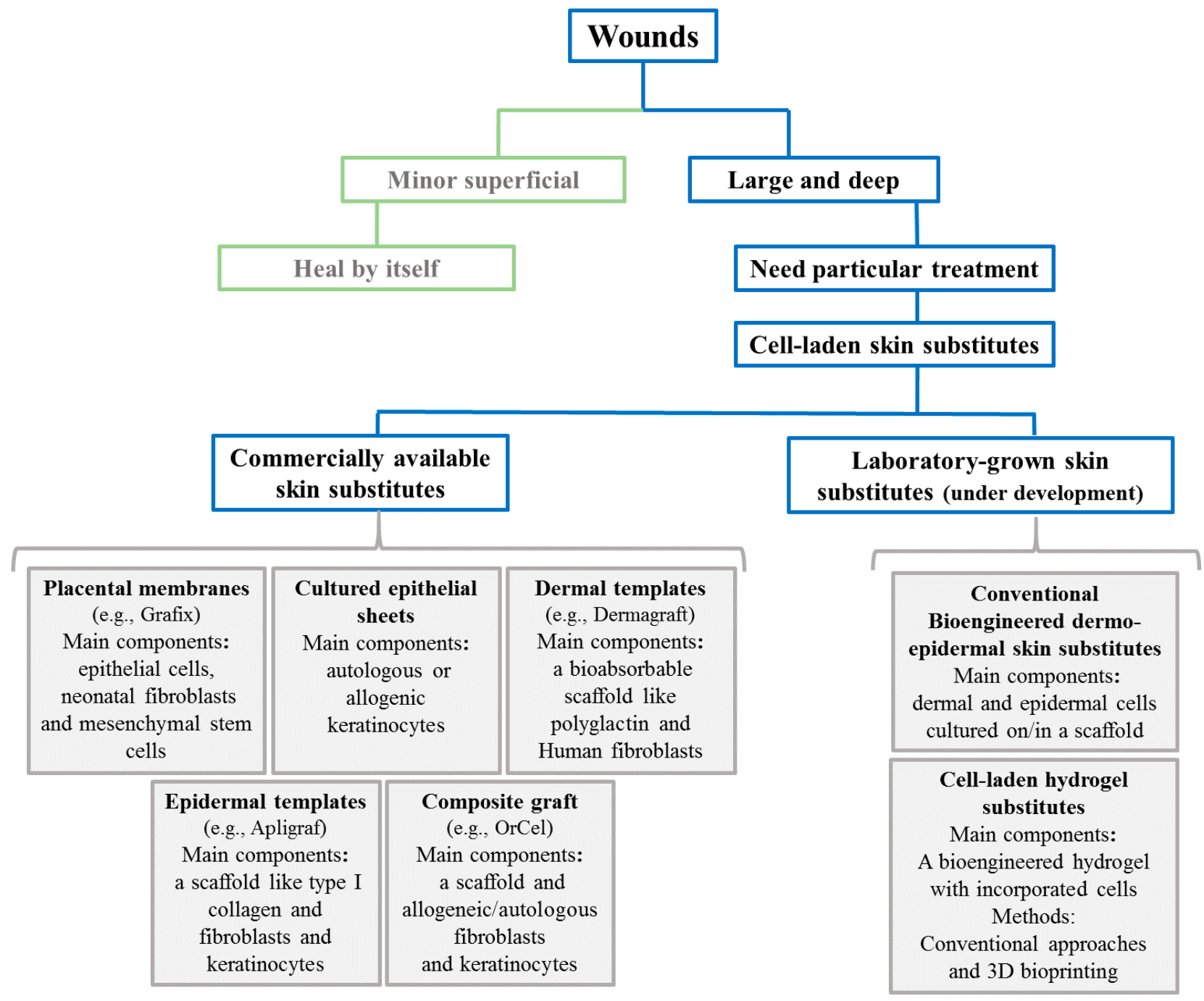

Figure 1. A schematic classification and summary of different commercial and bioengineered skin substitutes for large and hard-to-heal wounds.

\subsection{Cell-Laden Commercial Skin Templates}

Several commercially available skin substitutes have been developed applying different techniques and cell sources as explained below.

\subsubsection{Placental Membranes}

The placental membrane contains epithelial cells, neonatal fibroblasts, and mesenchymal stem cells (MSCs), promoting effectively wound healing [28]. MSCs produce factors that stimulate migration and proliferation of the main cell types in the wound healing process. MSCs also release the hepatocyte growth factor (HGF) and vascular endothelial growth factor (VEGF) to stimulate vascular network formation and provide anti-scarring properties, respectively [29]. Different studies have illustrated that MSCs improve tissue repair and skin regeneration and play a critical role in the major wound healing phases [30]. Additionally, MSCs can differentiate into multiple cell types and produce pro-regenerative cytokines. Therefore, MSCs-based skin substitutes provide an alternative option to conventional treatments for skin repair.

Grafix (Osiris Therapeutics Inc., Columbia, MD, USA) represents another commercially available placental-based cryopreserved allograft. It is used in different acute and chronic wounds such as diabetic foot ulcers, epidermolysis bullosa, burns, and surgical incisions and dehiscence [30,31]. Grafix employs the native constitutes of placental tissue, 
producing a 3D extracellular matrix (ECM) that includes various living cells including epithelial cells, fibroblasts, and MSCs [30]. Importantly, included fibroblasts also actively secrete ECM proteins along with growth factors, enriching the environment for epidermis formation and wound contraction [31]. Different clinical studies demonstrated that the treatment of difficult-to-heal chronic wounds with Grafix led to high wound closure rates, suggesting that Grafix represent a promising treatment option for wound therapy [30-33].

\subsubsection{Cultured Epithelial Sheets}

Recent advances in the tissue engineering field enabled the production of cultured epithelial autografts (CEA) used for wound coverage and healing [34,35]. CEA is composed of the patient's own keratinocytes (autologous) or donor cells (allografts) (sheets prepared from the skin of an unrelated donor). Thus, they represent an important life-saving treatment option for large burn injuries as well as for chronic ulcers [34,35]. In the case of burn wounds greater than $50 \%$ of the total body surface area, donor skin is limited [36]. Thus, cultured epithelial autografts offer potential coverage to support wound closure [35].

A first step toward the application of CEA was made by Green and Rheinwald, who have isolated and cultured human keratinocytes under in vitro culture conditions [37,38]. They also introduced irradiated 3T3 (murine fibroblasts) into the serial culture of human primary epidermal cells [37]. Finally, the achievements by Rheinwald and Green paved the way for the development and clinical application of CEA in the 1970s/1980s [36,38-42]. Since then, CEA was widely used for burn and reconstructive surgery worldwide [40-43].

However, the application potential of CEA is limited due to their inconsistent graft take rates, infection risk, and often unsatisfactory functional and aesthetic results $[40,44]$. The main reason for these problems is the lack of a functionally competent dermal component [44].

\subsubsection{Dermal Templates}

The dermis is the main layer of human skin with approximately $1 \mathrm{~mm}$ thickness. The Young's modulus of this layer ( 88 to $300 \mathrm{kPa}$ ) is much lower than that of the human epidermis, but it is stiffer than the subcutaneous fat layer (around $34 \mathrm{kPa}$ ) [27]. For dermal reconstruction, a bioscaffold with appropriate physical features, cellular cues, and mechanical properties, such as its elastic modulus and strength, which should be in the range of human dermal tissue, is required [45].

Dermagraft (Smith and Nephew, Largo, FL, USA) is a dermal substitute containing allogeneic human fibroblasts cultured in a polyglactin scaffold [46]. This scaffold is bioabsorbable, giving the product its structure and mechanical properties. Dermagraft is provided frozen in a clear bag containing one piece for a single-use application. It can be used for full-thickness diabetic foot ulcers for a long time and for deep necrotic cutaneous ulcers, which do not involve the tendon, muscle, and joint capsule or bone [46,47]. To engineer this dermal substitute, the fibroblasts are harvested from neonatal human foreskins and are cultured in vitro on a bioabsorbable polyglactin scaffold, which degrades by the hydrolysis process in 20-30 days [48]. Meanwhile, the fibroblasts proliferate to fill the interstices of this scaffold and secrete human dermal collagen, matrix proteins, growth factors, and cytokines. Thus, this bioscaffold creates a 3D human dermal substitute containing metabolically active living cells, helping to reconstitute a dermal layer. Numerous clinical studies demonstrated the efficiency of Dermagraft to heal chronic or difficult-to-heal wounds [49-53]. In a particular study by Omar et al., 18 patients with venous ulceration of the leg were recruited for the pilot study [52]. In this regard, 10 patients were treated with Dermagraft and compression therapy, and 8 patients of the other group were treated with compression therapy alone (control). The study demonstrated that patients treated with Dermagraft healed approximately four times faster than the control group by the end of the 12-week study period. Thus, Dermagraft was suggested as a promising dermal graft for the healing of hard wounds. However, Dermagraft does not contain macrophages, lymphocytes, blood vessels, or hair follicles [49]. Further disadvantages of Dermagraft 
are the necessity of multiple applications, safety issues owing to allogeneic cells, and high costs [1].

\subsubsection{Epidermal Templates}

The epidermis layer of human skin is the most superficial layer and has a thickness of approximately $0.1 \mathrm{~mm}$. This layer has the highest Young's modulus (approx. $1 \mathrm{MPa}$ ) in comparison with the other skin layers [27]. Epidermal tissue engineering approaches have focused on developing a stratified keratinocyte layer to provide barrier function, which is vitally important for body protection and long-term survival [54].

Various scaffolds using different materials have been utilized for this purpose. The scaffolds should be engineered in a way that provides a physical matrix to support cell migration and release of soluble factors such as chemokines and growth factors. These factors are important to improve epidermal cell migration as well as dermal repair and revascularization [54].

Apligraf (Organogenesis Inc., Canton, Massachusetts, CA, USA) is a bilayered bioengineered skin substitute (BBSS) composed of a bovine type I collagen lattice with a dermal layer of human fibroblasts and a layer formed by human keratinocytes, mimicking the normal structure of human skin [55]. Importantly, Apligraf is food and drug administration (FDA) approved for the treatment of partial- and full-thickness skin wounds. Further, it is used for wounds that extend through the dermis but do not involve muscle, tendon, joint capsule, or bone exposure [46]. Apligraf is also designated for use in standard diabetic foot ulcer care [52]. It provides essential ECM components to the wound bed, as well as cytokines and growth factors, such as platelet-derived growth factor (PDGF), interferons $\alpha$ and $\beta$ and, interleukins 16 and 8 [49]. However, there are no antigen-presenting cells such as dermal dendritic cells, Langerhans cells, endothelial cells, or immune cells in the BBSS. Additionally, no clinical rejection and no humoral or cellular response to the keratinocytes or fibroblasts of Apligraf has been reported performing immunological tests in clinical trials [55]. However, allogeneic cells of the construct do not survive longer than one to two months in vivo [56-58].

A clinical study by Eaglstein et al. applied Apligraf after excisional surgery on 107 patients, who were followed for up to one year [56]. The results indicated no clinical or laboratory evidence of rejection. However, graft persistence decreased after two weeks to one month after transplantation. Thus, although the Apligraf skin substitute is a safe and useful template, it can only be utilized as a temporary bioactive wound coverage.

\subsubsection{Dermo-Epidermal Skin Equivalents (Composite Graft)}

Composite allografts containing both major skin layers (dermis and epidermis) thus resembling closely the natural human skin tissue structure and function [24]. Composite grafts that include allogenic dermis with autografted epidermal keratinocytes permit rapid re-epithelialization with a non-immunogenic cellular epidermis. One significant benefit of the composite grafts is their one-step application procedure in comparison with dermal substitutes $[59,60]$. There are many bioengineered commercial composite skin grafts.

Alloskin (AlloSource, Centennial, CO, USA) is a composite allograft made from cadaveric tissue. This product is indicated for different acute and chronic wounds [25,59]. As Alloskin is applied only as temporary coverage, accordingly, no cellular DNA from the product was found in the wound 14-21 days post-implantation [49].

OrCel (Ortec International, Inc., New York, NY, USA) is another composite allograft synthesized by culturing allogeneic neonatal keratinocytes and fibroblasts in type I bovine collagen porous sponge with nonporous sides. In this substitute, fibroblasts are cultured in a bovine type I collagen sponge that has a non-porous collagen-gel coating. Subsequently, keratinocytes are added on top to create an epidermal layer [61]. This bilayered substitute can produce an array of growth factors such as VEGF, PDGF, fibroblast growth factor1 , keratinocyte growth factor- 1 , and transforming growth factor- $\alpha$, and other cytokines, which are all favorable for host cell proliferation, migration, and wound healing [61]. 
Moreover, OrCel is an FDA-approved substitute for reconstructions in hand release surgery in epidermolysis bullosa patients and at graft donor sites, and its safety and efficacy have been evaluated in some clinical studies [56]. In a particular study of Still et al. [61], OrCel graft was employed to treat split-thickness donor sites in severely burned patients. Their findings demonstrated that OrCel was more effective in facilitating rapid wound closure of split-thickness skin donor sites with reduced scarring as compared to Biobrane-L (UDL Laboratories, Inc., Rockford, IL, USA) used as a standard dressing. Accordingly, OrCel can be used as a promising treatment option that promotes and accelerates skin healing and reduce scarring.

\subsection{Bioengineered Dermo-Epidermal Skin Substitutes (Under Development)}

Treatment of extraordinarily large deep skin defects remains a great clinical challenge. Today's "gold standard" approaches to cover such skin defects are primarily split- and full-thickness skin autografts, as well as skin flaps, skin expansion techniques, and dermal substitutes [62-66]. Laboratory-grown skin substitutes offer a novel promising treatment option for patients suffering from severe, full-thickness skin injuries $[20,24,67,68]$. Those patients need an artificial skin substitute due to the shortage of healthy donor skin sites for autografts.

Therefore, our laboratory-Tissue Biology Research Unit (TBRU) at the University of Zurich, Switzerland, and several laboratories worldwide have developed dermo-epidermal skin substitutes (DESSs) containing both—dermal and epidermal skin layers [12,66-74]. Our hypothesis is that a skin substitute closely resembling native human skin can yield more satisfactory clinical results both functionally and cosmetically. Of note, the addition of the missing dermal component significantly enhanced the mechanical stability and mesenchymal-epithelial interaction of those skin substitutes.

Moreover, our laboratory also investigated the mechanical modifications of the dermal compartment for better surgical handling [71,75]. Consequently, we developed a plastically compressed hydrogel based on a collagen type I matrix serving as a dermal template for DESSs [71]. Uncompressed collagen hydrogels are fragile and fold when manipulated with forceps, but after plastic compression, they are significantly more stable, which improves handling. Importantly, this dermal template has been successfully used for the establishment of large DESSs $(7.5 \times 7.5 \mathrm{~cm})$ and was eventually tested in a pig animal model $[36,37,71-77]$.

Recently, these autologous human DESSs (DenovoSkin) were successfully used in phase I clinical trial on 10 children at the University Children's Hospital, Zurich [75]. We recently started a phase II clinical trial in various burn and reconstructive surgery centers in Switzerland (University Children's Hospital Zurich, University Hospital Zurich) and Europe using those autologous skin grafts [75].

However, the prevalent challenge facing this innovative approach is the lack of sufficient vascularization to support the survival and viability of the above-mentioned DESSs after transplantation. This aspect is of utmost importance for the treatment of non-healing chronic wounds.

In a pilot study, we overcame these hurdles by the in vitro generation of capillary networks in DESSs using endothelial and mesenchymal progenitors derived from the stromal vascular fraction (SVF) of human adipose tissue (Figure 2) [12,13,20]. This approach holds great promise for future clinical applications as adipose tissue represents a convenient, abundant, and easily accessible cell source [78]. Moreover, this concept was previously successfully used in the engineering of precisely sized osteogenic constructs, increasing the efficiency and uniformity of bone tissue formation [79]. 
21 days in vitro

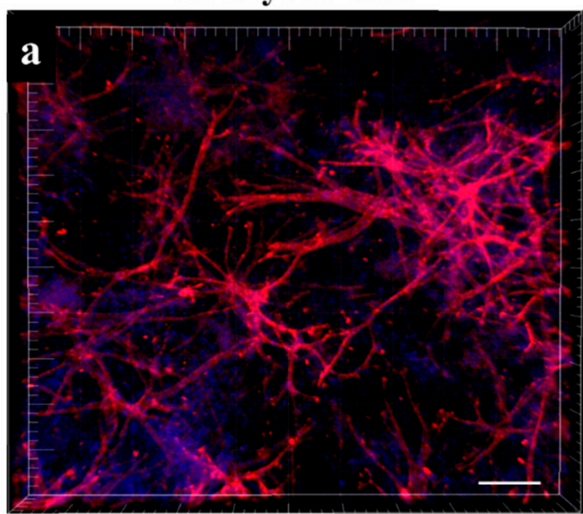

4 days in vivo

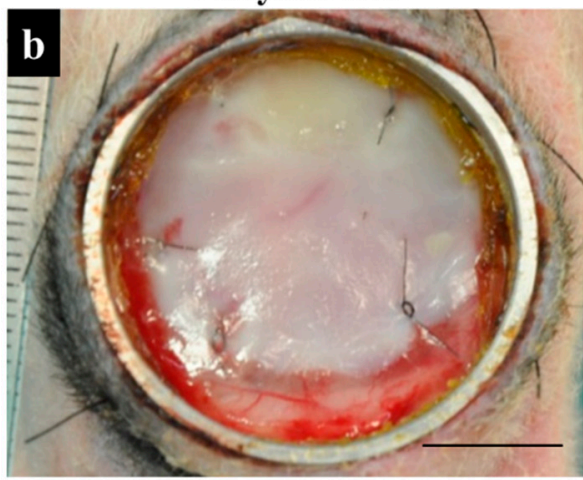

7 days in vivo

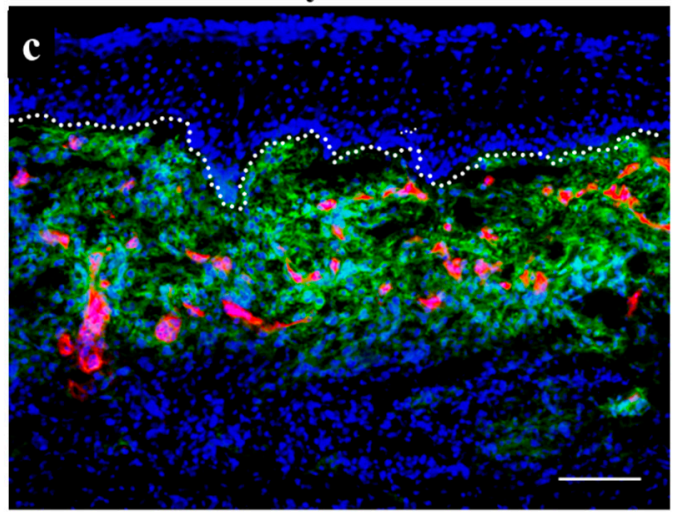

7 days in vivo

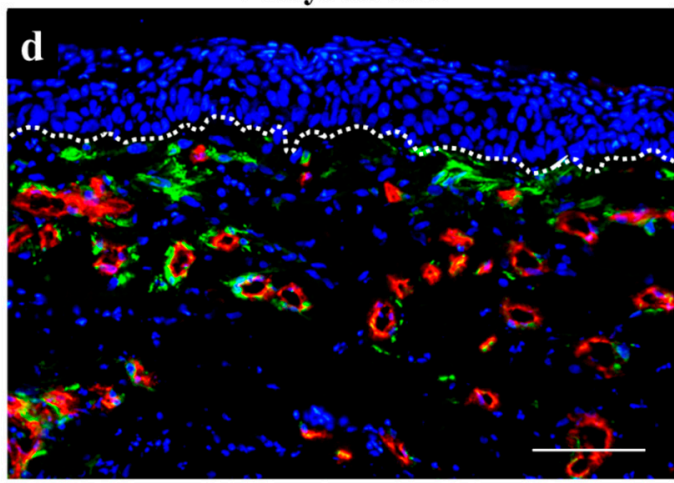

Figure 2. (a) A collagen type I hydrogel containing human adipose-derived microvascular networks cultured for 21 days in vitro, (b) A pre-vascularized bioengineered human dermo-epidermal skin substitute 7 days after transplantation onto the back of nu/nu rat, (c) Human engineered capillaries are visualized by the human-specific CD31-antibody (red) present in the CD90-positive (green) human neo-dermis. (d) Human CD31-capillaries (red) co-stained by human/rat alpha smooth muscle actin ( $\alpha \mathrm{SMA}$ ) (pericyte marker; green). HoechstI stains the nuclei in blue. White dotted line indicates the dermo-epidermal junction. Scale bar $=100 \mu \mathrm{m}(\mathbf{a}-\mathbf{d})$ and $1 \mathrm{~cm}(\mathbf{b})[12,20]$.

Importantly, the rapid onset of blood infiltration in the skin substitutes had efficient effects on promoting epithelial and dermal tissue repair in vivo by (1) increased collagen type I expression, (2) elevated cell proliferation rate of both dermis and epidermis, (3) improved graft take rate, (4) reduced expression of wound healing markers such as cytokeratin 16 (CK16) and cytokeratin 17 (CK17), and (5) rapid achievement of epidermal homeostasis. These results confirm that such a co-culture-based pre-vascularization strategy of tissue-engineered skin grafts emerges as an efficient method to noticeably improve wound healing, cell engraftment, and skin function after transplantation [20].

\subsubsection{Cell-Laden Hydrogels as Wound Dressings}

More recently, attention has been attracted to engineering hydrogels as skin templates to encapsulate cells and bio-macromolecules to support cell-cell and cell-microenvironment interactions.

Due to their attractive properties, hydrogels are the most common materials used as a scaffold to culture cells for skin repair applications. Hydrogels can provide an appropriate scaffold for cell encapsulation due to their 3D matrix, which is replete with water and their biodegradability properties. Additionally, the majority of them are biocompatible, which means the hydrogel does not provoke any adverse reaction, rejection, or immune response upon implantation [80-84]. Furthermore, mechanical properties of hydrogels including stiffness, viscoelastic behavior, and initial state recovery (self-healing) are tunable by copolymerization, nanoparticle incorporation, and changing the polymer concentrations 
and ratios $[3,83,84]$. Moreover, hydrogels are biomimetic structures, mimicking the natural microenvironment enabling cell-cell interactions and interactions with the surrounding tissue $[85,86]$.

There are some commercial cell-laden hydrogels available on the market. TransCyte (Advanced BioHealing, Inc., New York, NY, USA and La Jolla, CA, USA) is a bio-engineered skin wound dressing, formerly marketed as Dermagraft-Transitional Covering [87]. This dermal substitute is composed of human newborn fibroblasts, which are then seeded on the nylon mesh of Biobrane with a thin silicone layer regulating moisture vapor from the wound. TransCyte can be applied to the wound site and is protected by adhesive strips; in some cases, surgical staples are used [88].

In general, Figure 3 represents a concept of a cell-laden hydrogel for skin tissue engineering. First, cells are isolated from a patient and cultured in a hydrogel matrix. The hydrogel supports the growth of cells and skin formation, which can be grafted back to treat the skin defect of the patient. Cell-laden hydrogels are usually prepared by mixing the isolated cells in a pre-polymer solution followed by a crosslinking using an ionic or chemical crosslinking such as a thermal or photo-crosslinking mechanism. However, the type of photoinitiator, light, and temperature need to be controlled to protect the cells and increase their viability after crosslinking [3,89-91].

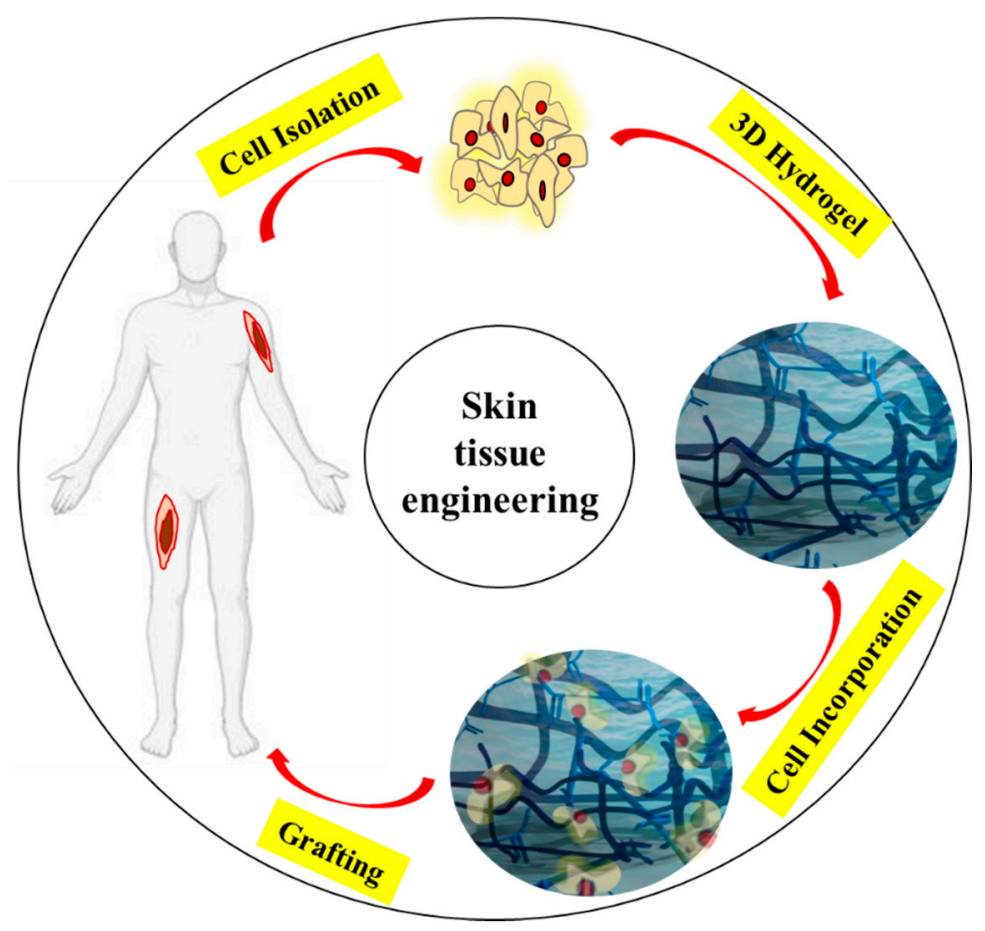

Figure 3. Schematic representing the preparation process of a cell-laden hydrogel in which cells from an isolated donor are placed and then cultured in a 3D hydrogel matrix and grafted to a skin defect as a skin substitute.

There are different kinds of cell-laden hydrogels, which can be divided based on their scaffold structure such as porous and stimuli-responsive hydrogels. In porous hydrogels, a porous bioscaffold containing cells forms a foam or crosslinked hydrogel, which can be applied as a skin substitute onto a wound site [91,92]. In particular, porosity plays a critical role to allow host cell infiltration into the 3D network and to improve protein transport and diffusion to mimic native tissue structure and function. For instance, if the pores are too small, they might be blocked by cellular penetration, ECM formation, and vascularization of the inner areas of the scaffold [81]. When designing a hydrogel scaffold for tissue engineering purposes, pore-related parameters including morphology, 
volume, size, distribution, throat size, wall roughness, and the interconnectivity of pores are important [93].

It has been demonstrated that the optimum pore size is $5-15 \mu \mathrm{m}$ for ingrowth of fibroblast, $20 \mu \mathrm{m}$ for hepatocyte ingrowth, and $20-125 \mu \mathrm{m}$ for the regeneration of adult mammalian skin $[94,95]$. Thus, pore size and distribution should be taken into consideration while engineering hydrogels for skin tissue engineering and to mimic native skin structure.

On the other hand, several scaffolds have been developed using stimuli-responsive materials that can release the encapsulated cells and biomolecules into the host tissue when triggered by different internal or external stimuli. To synthesize such a scaffold, first, a stimuli-responsive polymer is mixed with cells; second, the pre-gel solution is applied via injecting/spraying on the wound site [96]. Then, due to the external stimuli like thermal or photo stimulators, the polymer forms a physical gel leading to cell encapsulation within a 3D scaffold.

The in situ formation of cell/hydrogel scaffold structure facilitates the delivery of encapsulated cells, growth factors, and necessary nutrients at the wound site via using negligibly invasive techniques [97]. Various studies have been conducted using stimuli-responsive materials. For instance, in the study of Eke et al. [98], a UV-crosslinked biodegradable hydrogel was employed as a scaffold containing adipose-derived stem cells (ADSCs) to stimulate vascularization in difficult-to-heal wounds. In this study, methacrylated gelatin (GelMA) and methacrylated hyaluronic acid (HAMA) were used to synthesize the hydrogel network. Afterward, a photoinitiator, to induce photo-crosslinking, and cells were added simultaneously into the pre-hydrogel solution (Figure 4a). The mechanical stability of composite hydrogels was engineered by varying the GelMA and HAMA concentrations and ratios. Although the modulus of this hydrogel $(6 \mathrm{kPa})$ is lower than that of native skin, it proved to be easy to handle and manipulate, which is important in the laboratory and in the clinics. Further, in vitro results showed that those hydrogels provide an appropriate microenvironment for the proliferation of ADSCs. Additionally, in vivo studies demonstrated that stem-cell-loaded hydrogel scaffolds significantly improved vascularization at the wound site compared to their cell-free counterpart groups (Figure 4b) [98].

\subsubsection{D Bioprinting of Cell-Laden Hydrogels for Wound Dressings}

There are various approaches to produce cell-laden hydrogels for skin engineering [99]. Recently, 3D printing of cell-laden hydrogels emerged as a novel fabrication technique. This method involves the printing of hydrogel with cells in a layer-by-layer manner to fabricate a complex bioscaffold [100]. The main advantage of this method in skin engineering is the ability to develop clinically relevant skin constructs that closely mimic the native skin architecture and heterogeneity. However, the success of bioprinting for skin regeneration is strictly dependent on the engineering of appropriate printable bioinks to support the function of cells and stimulate the fabrication of new ECM after printing. Hydrogel-based materials are one of the most promising bioinks for skin regeneration applications, as they have some unique properties such as their tunable rheological behavior, which is vitally important for delivering cells by printing $[89,98]$.

Several review papers have extensively discussed the main aspects of 3D bioprinting and its different techniques [101-103]. Here, we mention some recent studies regarding cell-laden hydrogel-based skin substitutes developed via 3D bioprinting.

Although there are various hydrogels used for bioprinting, they are mainly restricted to natural polymers such as alginate, collagen, gelatin, fibrin, and hyaluronic acid $[104,105]$. In a study by Cubo et al. [106], the authors used a 3D bioprinter to produce a human-plasmaderived bilayered skin for the treatment of burn injuries and traumatic and surgical wounds. The authors used primary human fibroblasts and keratinocytes that were obtained from skin biopsies [106]. The dermal part was formed by printing human fibroblasts embedded within a plasma-derived fibrin hydrogel. Their results showed the production of skin equivalents with structural resemblance to the human skin, confirmed by the presence 
of fibroblasts spread within the dermal compartment and the terminal differentiation of keratinocytes.

a
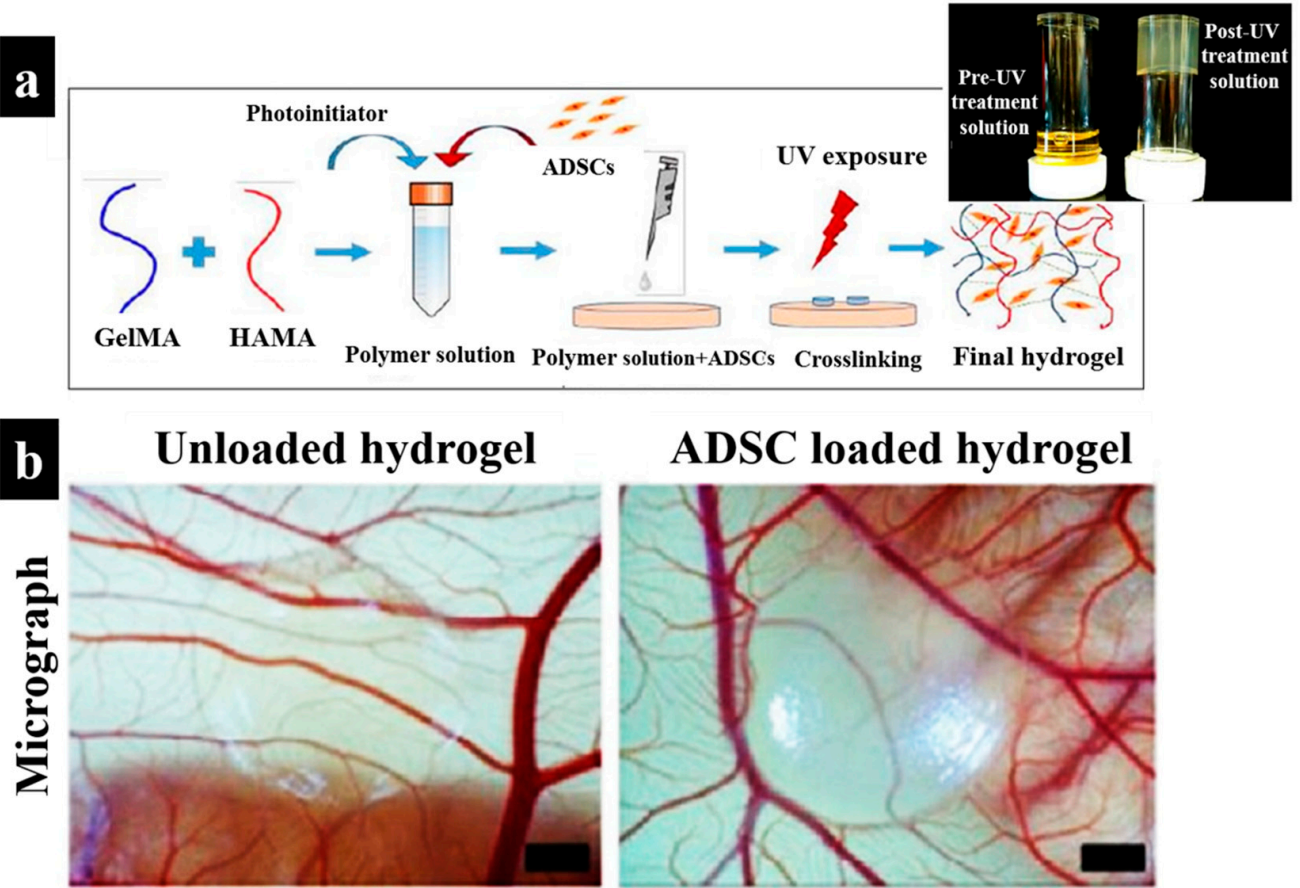

ADSC loaded hydrogel
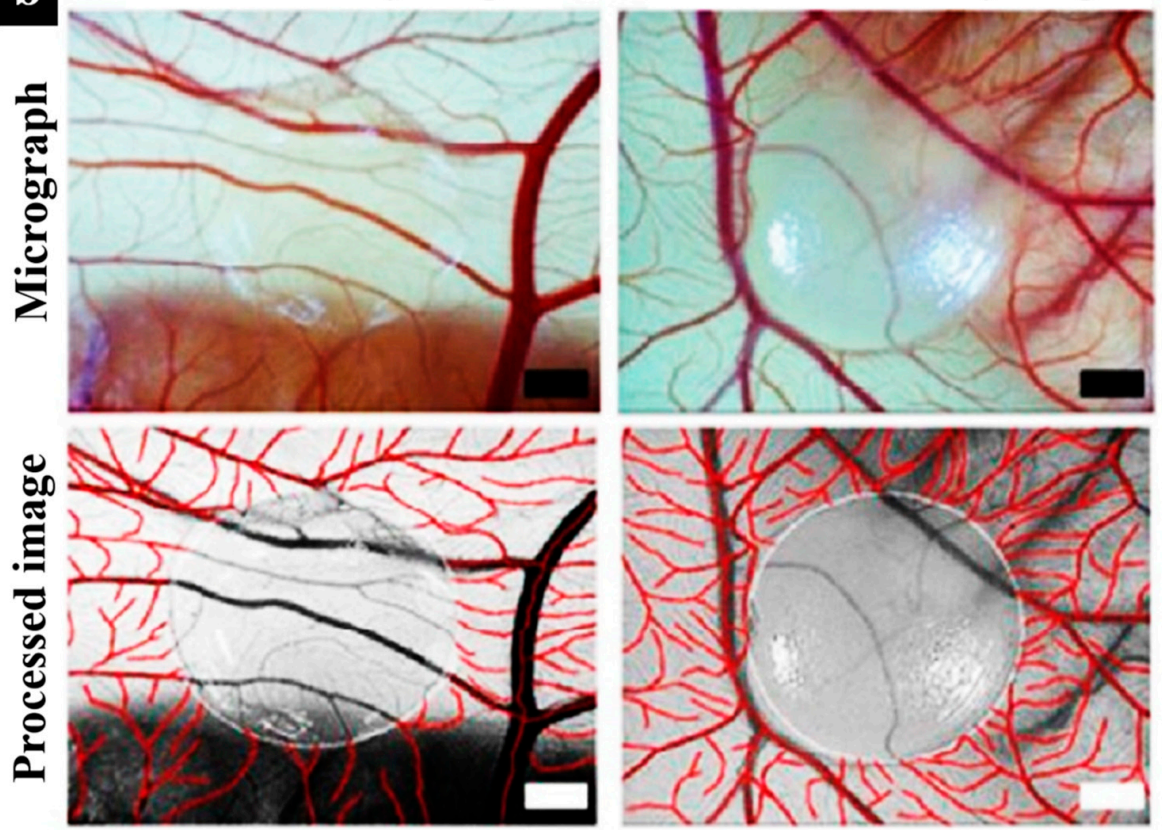

Figure 4. (a) Schematic demonstrating methacrylated gelatin (GelMA) acid methacrylated hyaluronic acid (HAMA) chain integration to prepare polymer solution. Furthermore, the addition of a photoinitiator to prepare a UV-crosslinkable hydrogel containing adipose-derived stem cells (ADSCs) to produce a cell-laden hydrogel wound dressing. Gel solution before (left picture) and after (right picture) $50 \mathrm{~s}$ of UV exposure. And (b) Angiogenic characteristics of the bicomponent network (BCN) hydrogel in the chick chorioallantoic membrane (CAM) test. Micrographs (upper pictures) and semi-automatic treated images (lower pictures) of the hydrogel and hydrogel-loaded ADSCs, taken on day 14 of embryonic development [98].

In another study, Yanez et al. [107] employed the 3D bioprinting technology to integrate capillary-like endothelial networks into a dermo-epidermal skin graft including neonatal human epidermal keratinocytes (NHEKs) and neonatal human dermal fibroblasts (NHDFs), both embedded in a fibrin-collagen hydrogel matrix. In this work, human dermal microvascular endothelial cells) were mixed with thrombin and printed on top of a manually plated layer of collagen-NHDF cells containing fibrinogen. After synthesis of the fibrin hydrogel, a layer of collagen-containing NHEK cells was pipetted on top of it to create a bilayered network. In order to take into account in vivo considerations, printed structures were implanted into skin full-thickness wounds on the back of athymic nude mice to examine the healing process. Wound treating behavior was compared with control (no treatment) and Apligraf (discussed previously) groups. Wounds healed with printed substitutes needed 14-16 days to heal, contrasting with 21 days in the control group and 
28 days in the group implanted with Apligraf [107]. Moreover, histological characterization demonstrated the formation of dermal and epidermal skin layers comparable to the native skin, which is accompanied by the presence of new microvessels in the mouse tissue. The authors concluded that the neoangiogenesis was triggered mainly by the presence of endothelial cells that were seeded in the skin graft. In addition, human keratinocytes which are known to secrete various angiogenic growth factors stimulated vascularization [107].

Further, Hakimi et al. [108] developed a handheld skin printer that allowed in situ formation of skin tissue sheets of different homogeneous and architected compositions (Figure 5). They demonstrated that this system is compatible with dermal and epidermal cells incorporated with ionic crosslinkable alginate, enzymatically crosslinkable proteins (e.g., fibrin), and their mixtures with collagen type I and hyaluronic acid. Additionally, in a study by Liu et al. [109], a cell-laden alginate/gelatin temperature-dependent hydrogel was used as a bioink for an extrusion-based 3D bioprinting using amniotic epithelial cells and Wharton's-jelly-derived mesenchymal stem cells. In this study, the hydrogel bioink was engineered by changing the alginate/gelatin concentration ratio to achieve optimum rheological properties for 3D printing.

There are other recent research examples on developing cell-laden hydrogel bioinks to print skin layers or substitutes, focusing on natural hydrogels [110-116]. However, it is vitally important to design specific physical, mechanical, and biological properties of hydrogel bioinks by modification of the gel composition, concentration, and ratios to provide promising biomaterials for future skin tissue engineering applications. Generally, an appropriate hydrogel bioink should be cell compatible and able to incorporate/encapsulate cells before and after crosslinking. Moreover, hydrogels should have an optimum viscosity and shear-thinning behavior to maintain the steady state of the gel and protect cells during printing, especially for extrusion-based 3D printers. Moreover, the bioink hydrogel should mimic the physical and mechanical features of native skin after printing to produce appropriate cues for cells to differentiate and proliferate. 

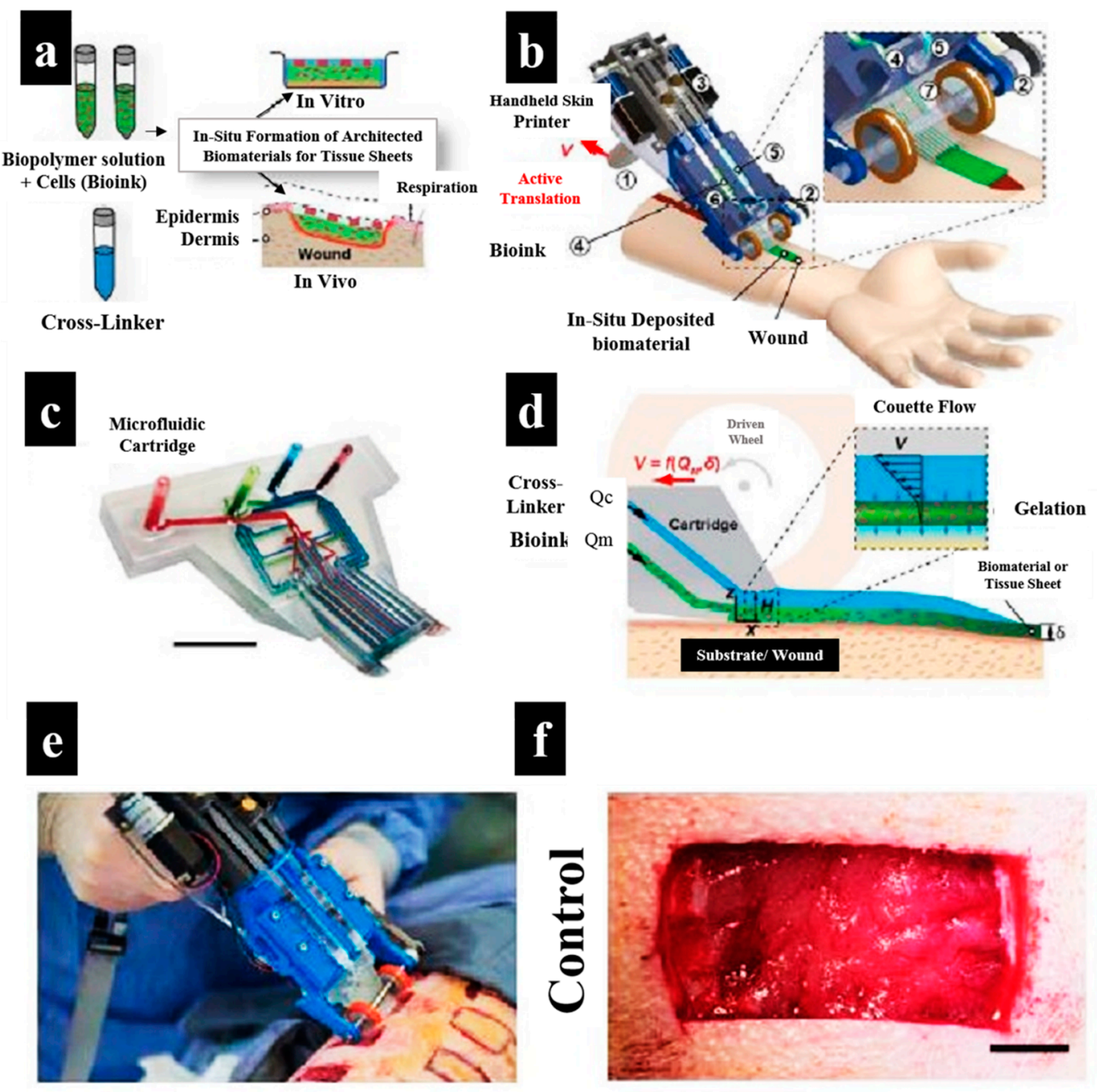

f
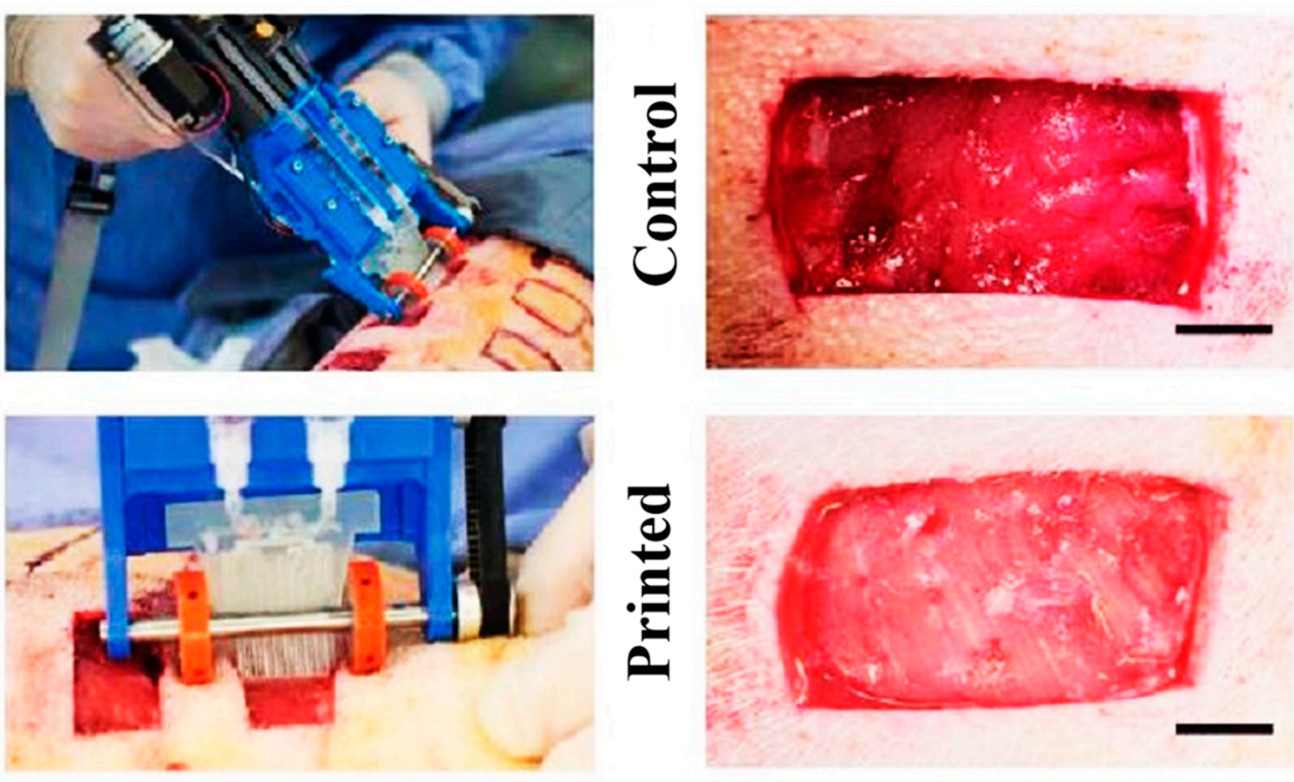

Figure 5. Handheld skin printer. (a) Schematic diagram demonstrating the working principle of handheld bioprinter. One or several bioink solutions (green color), containing premixed biomaterials and cells are arranged. The handheld bioprinter transforms bioinks into homogenous or architected biomaterial sheets or tissues directly within a culture dish or a wound site. (b) Rendered image of handheld bioprinter. A handle (1) enables positioning above the target surface or wound. A stepper motor, pulley, and drive mechanism (2) define the deposition speed, V. Two on-board syringe pump modules (3) control the dispensing flow rates for bioink (4) and crosslinker solution (5). 3D printed microfluidic cartridge (6) for the spatial organization of solutions and sheet formation. (c) Photograph of 3D printed microfluidic cartridge. Scale bar $10 \mathrm{~mm}$. (d) Schematic side-view image demonstrating sheet formation between the moving microfluidic cartridge and the deposition surface or wound. (e) Representative photograph showing in situ deposition of $\delta=250 \mu \mathrm{m}$ thick fibrin-hyaluronic acid/collagen sheet on top of a full-thickness excisional porcine wound using a handheld skin printer. (top) Close-up view of sheet formation within wound bed with a $2 \mathrm{~cm}$ microfluidic cartridge (bottom) (f) (Control, not printed) on day 0 and printed 5 min after in situ formation of biomaterial sheet [108]. 


\section{Conclusions and Future Direction}

Large and deep skin defects and non-healing chronic wounds still pose a significant challenge to the clinicians. Not only should ideal skin coverage protect the wound and increase tissue regeneration, but it should also improve patients' aesthetics, satisfaction, and wellbeing. Therefore, considerable progress has been made over recent years in the field of skin tissue engineering. Various skin substitutes based on synthetic or natural scaffolds and bioengineered skin substitutes have been developed to find the ideal skin replacement for use in acute and chronic skin wounds.

Further, 3D bioprinting technology, emerged as a convenient method to fabricate skin substitutes using primary cells made using the patients' skin cells. Although, this technology is still in its infancy, it will be further developed in the near future.

Importantly, the prevascularization approach has emerged as another promising concept in skin tissue engineering. This approach aims at the generation of preformed microvascular networks inside skin substitutes prior to their transplantation and offers an advantage especially in treating chronic wounds.

To conclude, these different approaches to design novel skin substitutes, including the use of stem cells, prevascularization and 3D bioprinting give new hope that the ideal skin substitute may soon become a reality.

Author Contributions: A.S.K. conceptualized this study and edited. and provided critical revision of the finalized manuscript S.T. performed the literature search and drafted the manuscript. All authors have read and agreed to the published version of the manuscript.

Funding: This research received funding from the Olga Mayenfisch Foundation, SNF Sinergia Project no CRSII5_173868 "A Tissue, Cell, and Molecular Approach to Understanding and Treating Microtia “and ITN EU project SkinTERM. no 955722. Additionally, the authors are particularly grateful to the Foundation Gaydoul for their generous financial support.

Institutional Review Board Statement: The study was conducted according to the guidelines of the Declaration of Helsinki, and approved by the cantonal Ethics Committee (EKBB, Ref. 78/07 and BASEC-Request No. 2018-00269).

Informed Consent Statement: Informed consent was obtained from all subjects involved in this study.

Conflicts of Interest: The authors declare no conflict of interest.

\section{References}

1. Shevchenko, R.V.; James, S.E. A review of tissue-engineered skin bioconstructs available for skin reconstruction. J. R. Soc. Interface 2009, 7, 229-258. [CrossRef] [PubMed]

2. Lazarus, G.S.; Cooper, D.M.; Knighton, D.R.; Margolis, D.J.; Percoraro, R.E.; Rodeheaver, G.; Robson, M.C. Definitions and guidelines for assessment of wounds and evaluation of healing. Wound Repair Regen. 1994, 2, 165-170. [CrossRef]

3. Tavakoli, S.; Mokhtari, H.; Kharaziha, M.; Kermanpur, A.; Talebi, A.; Moshtaghian, J. A multifunctional nanocomposite spray dressing of Kappa-carrageenan-polydopamine modified ZnO/L-glutamic acid for diabetic wounds. Mater. Sci. Eng. C 2020, 111, 110837. [CrossRef] [PubMed]

4. Kanitakis, J. Anatomy, histology and immunohistochemistry of normal human skin. Eur. J. Dermatol. 2002, 12, 390-401.

5. Schmook, F.P.; Meingassner, J.G.; Billich, A. Comparison of human skin or epidermis models with human and animal skin in in-vitro percutaneous absorption. Int. J. Pharm. 2001, 215, 51-56. [CrossRef]

6. Tavakoli, S.; Klar, A.S. Advanced Hydrogels as Wound Dressings. Biomolecules 2020, 10, 1169. [CrossRef]

7. Subramanian, A.; Krishnan, U.M.; Sethuraman, S. Skin tissue regeneration. In Electrospinning for Tissue Regeneration; Woodhead Publishing: Cambridge, UK, 2011; Volume 1, pp. 298-316. [CrossRef]

8. Rowan, M.P.; Cancio, L.C.; Elster, E.A.; Burmeister, D.M.; Rose, L.F.; Natesan, S.; Chan, R.K.; Christy, R.J.; Chung, K.K. Burn wound healing and treatment: Review and advancements. Crit. Care 2015, 19, 1-12. [CrossRef] [PubMed]

9. Boateng, J.S.; Matthews, K.H.; Stevens, H.N.; Eccleston, G.M. Wound Healing Dressings and Drug Delivery Systems: A Review. J. Pharm. Sci. 2008, 97, 2892-2923. [CrossRef]

10. Gaur, M.; Dobke, M.K.; Lunyak, V.V. Mesenchymal Stem Cells from Adipose Tissue in Clinical Applications for Dermatological Indications and Skin Aging. Int. J. Mol. Sci. 2017, 18, 208. [CrossRef]

11. Roupé, K.M.; Nybo, M.; Sjöbring, U.; Alberius, P.; Schmidtchen, A.; Sørensen, O.E.; Roup, M.N.K.M. Injury Is a Major Inducer of Epidermal Innate Immune Responses during Wound Healing. J. Investig. Dermatol. 2010, 130, 1167-1177. [CrossRef] 
12. Klar, A.S.; Güven, S.; Zimoch, J.; Zapiórkowska, N.A.; Biedermann, T.; Böttcher-Haberzeth, S.; Meuli-Simmen, C.; Martin, I.; Scherberich, A.; Reichmann, E.; et al. Characterization of vasculogenic potential of human adipose-derived endothelial cells in a three-dimensional vascularized skin substitute. Pediatr. Surg. Int. 2015, 32, 17-27. [CrossRef]

13. Klar, A.S.; Michalak-Mićka, K.; Biedermann, T.; Simmen-Meuli, C.; Reichmann, E.; Meuli, M. Characterization of M1 and M2 polarization of macrophages in vascularized human dermo-epidermal skin substitutes in vivo. Pediatr. Surg. Int. 2017, 34, 129-135. [CrossRef]

14. Delavary, B.M.; Van Der Veer, W.M.; Van Egmond, M.; Niessen, F.B.; Beelen, R.H. Macrophages in skin injury and repair. Immunobiology 2011, 216, 753-762. [CrossRef]

15. Sukari, H.A.; Khoo, T.L.; Yussof, S.J. Biologic and synthetic skin substitutes: An overview. Indian J Plast Surg 2010, 43, 23-28. [CrossRef]

16. Harding, K.G.; Morris, H.L.; Patel, G.K. Science, medicine, and the future: Healing chronic wounds. BMJ 2002, 324, 160-163. [CrossRef]

17. Guo, S.; DiPietro, L.A. Critical Review in Oral Biology \& Medicine: Factors Affecting Wound Healing. J. Dent. Res. 2010, 89, 219-229. [CrossRef]

18. Johnson, K.E.; Wilgus, T.A. Vascular Endothelial Growth Factor and Angiogenesis in the Regulation of Cutaneous Wound Repair. Adv. Wound Care (New Rochelle) 2014, 3, 647-661. [CrossRef]

19. Demidova-Rice, T.N.; Durham, J.T.; Herman, I.M. Wound Healing Angiogenesis: Innovations and Challenges in Acute and Chronic Wound Healing. Adv. Wound Care 2012, 1, 17-22. [CrossRef] [PubMed]

20. Klar, A.S.; Güven, S.; Biedermann, T.; Luginbühl, J.; Böttcher-Haberzeth, S.; Meuli-Simmen, C.; Meuli, M.; Martin, I.; Scherberich, A.; Reichmann, E. Tissue-engineered dermo-epidermal skin grafts prevascularized with adipose-derived cells. Biomaterials 2014, 35, 5065-5078. [CrossRef] [PubMed]

21. Frueh, F.S.; Macedo, N.; Calcagni, M.; Giovanoli, P.; Lindenblatt, N. The Crucial Role of Vascularization and Lymphangiogenesis in Skin Reconstruction. Eur. Surg. Res. 2018, 59, 242-254. [CrossRef] [PubMed]

22. Shahin, H.; Elmasry, M.; Steinvall, L.; Söberg, F.; Serafi, A. Vascularization is the next challenge for skin tissue engineering as a solution for burn management. Burns Trauma 2020, 8, 022. [CrossRef] [PubMed]

23. Klar, A.S.; Böttcher-Haberzeth, S.; Biedermann, T.; Schiestl, C.; Reichmann, E.; Meuli, M. Analysis of blood and lymph vascularization patterns in tissue-engineered human dermo-epidermal skin analogs of different pigmentation. Pediatr. Surg. Int. 2014, 30, 223-231. [CrossRef]

24. Pourmoussa, A.; Gardner, D.J.; Johnson, M.B.; Wong, A.K. An update and review of cell-based wound dressings and their integration into clinical practice. Ann. Transl. Med. 2016, 4, 457. [CrossRef]

25. Klar, A.S.; Biedermann, T.; Simmen-Meuli, C.; Reichmann, E.; Meuli, M. Comparison of in vivo immune responses following transplantation of vascularized and non-vascularized human dermo-epidermal skin substitutes. Pediatr. Surg. Int. 2016, 33, 377-382. [CrossRef]

26. Pogorielov, M.; Hapchenko, A.; Pogorielov, O.O.M. Tissue Engineering: Challenges and Selected Application. Adv. Tissue Eng. Regen. Med. Open Access 2017, 3, 1-6. [CrossRef]

27. Li, C.; Guan, G.; Reif, R.; Huang, Z.; Wang, R.K. Determining elastic properties of skin by measuring surface waves from an impulse mechanical stimulus using phase-sensitive optical coherence tomography. J. R. Soc. Interface 2011, 9, 831-841. [CrossRef]

28. Olena, P.; Prokopyuk, V.; Figueiredo, C.; Pogozhykh, D. Placenta and Placental Derivatives in Regenerative Therapies: Experimental Studies, History, and Prospects. Stem Cells Int. 2018, 2018, 1-14. [CrossRef]

29. Maxson, S.; Lopez, E.A.; Yoo, D.; Danilkovitch-Miagkova, A.; Leroux, M.A. Concise Review: Role of Mesenchymal Stem Cells in Wound Repair. STEM CELLS Transl. Med. 2012, 1, 142-149. [CrossRef]

30. Lavery, L.A.; Fulmer, J.; Shebetka, K.A.; Regulski, M.; Vayser, D.; Fried, D.; Kashefsky, H.; Owings, T.M.; Nadarajah, J. The Grafix Diabetic Foot Ulcer Study Group The efficacy and safety of Grafix ${ }^{\circledR}$ for the treatment of chronic diabetic foot ulcers: Results of a multi-centre, controlled, randomised, blinded, clinical trial. Int. Wound J. 2014, 11, 554-560. [CrossRef] [PubMed]

31. Wong, T.; McGrath, J.A.; Navsaria, H. The role of fibroblasts in tissue engineering and regeneration. Br. J. Dermatol. 2007, 156, 1149-1155. [CrossRef]

32. Gibbons, G.W. Grafix ${ }^{\circledR}$, a Cryopreserved Placental Membrane, for the Treatment of Chronic/Stalled Wounds. Adv. Wound Care 2015, 4, 534-544. [CrossRef]

33. Landsman, A.S.; Cook, J.J.; Cook, A.E.; Landsman, A.R.; Garrett, P.; Yoon, J.; Kirkwood, A.; Desman, E. A Retrospective Clinical Study of 188 Consecutive Patients to Examine the Effectiveness of a Biologically Active Cryopreserved Human Skin Allograft (TheraSkin ${ }^{\circledR}$ ) on the Treatment of Diabetic Foot Ulcers and Venous Leg Ulcers. Foot Ankle Spéc. 2010, 4, 29-41. [CrossRef]

34. Wood, F.M.; Kolybaba, M.; Allen, P. The use of cultured epithelial autograft in the treatment of major burn wounds: Eleven years of clinical experience. Burns 2006, 32, 538-544. [CrossRef] [PubMed]

35. Gao, Z.-R.; Hao, Z.-Q.; Nie, L.-J.; Liu, G.-F. Coverage of full skin thickness burns with allograft inoculated with autogenous epithelial cells. Burns 1986, 12, 220-224. [CrossRef]

36. Barret, P.J.; Wolf, S.E.; Desai, M.H.; Herndon, D.N. Cost-Efficacy of Cultured Epidermal Autografts in Massive Pediatric Burns. Ann. Surg. 2000, 231, 869-876. [CrossRef]

37. Rheinwatd, J.G.; Green, H. Seria cultivation of strains of human epidemal keratinocytes: The formation keratinizin colonies from single cell is. Cell 1975, 6, 331-343. [CrossRef] 
38. Rheinwald, J.G.; Green, H. Epidermal growth factor and the multiplication of cultured human epidermal keratinocytes. Nat. Cell Biol. 1977, 265, 421-424. [CrossRef]

39. Gobet, R.; Raghunath, M.; Altermatt, S.; Meuli-Simmen, C.; Benathan, M.; Dietl, A.; Meuli, M. Efficacy of cultured epithelial autografts in pediatric burns and reconstructive surgery. Surgery 1997, 121, 654-661. [CrossRef]

40. Atiyeh, B.S.; Costagliola, M. Cultured epithelial autograft (CEA) in burn treatment: Three decades later. Burns 2007, 33, 405-413. [CrossRef]

41. Ronfard, V.; Rives, J.M.; Neveux, Y.; Carsin, H.; Barrandon, Y. Long-term regeneration of human epidermis on third degree burns transplanted with autologous cultured epithelium grown on a fibrin matrix1, 2. Transplantation 2000, 70, 1588-1598. [CrossRef] [PubMed]

42. Cuono, C.; Langdon, R.; McGuire, J. Use of cultured epidermal autografts and dermal allografts as skin replacement after burn injury. Lancet 1986, 327, 1123-1124. [CrossRef]

43. Meuli, M.; Raghunath, M. Tops and flops using cultured epithelial autografts in children. Pediatr. Surg. Int. 1997, 12, 471-477. [CrossRef] [PubMed]

44. Krupp, S.; Benathan, M.; Meuli, M.; Déglise, B.; Holzer, E.; Wiesner, L.; Delacrétaz, F.; Chioléro, R. Current Concepts in Pediatric Burn Care: Management of Burn Wounds with Cultured Epidermal Autografts*. Eur. J. Pediatr. Surg. 1992, 2, 210-215. [CrossRef] [PubMed]

45. Bhardwaj, N.; Sow, W.T.; Devi, D.; Ting, S.W.; Mandal, B.B.; Cho, N.-J. Silk fibroin-keratin based 3D scaffolds as a dermal substitute for skin tissue engineering. Integr. Biol. 2014, 7, 53-63. [CrossRef]

46. Marston, W.A.; Hanft, J.; Norwood, P.; Pollak, R. The Efficacy and Safety of Dermagraft in Improving the Healing of Chronic Diabetic Foot Ulcers: Results of a prospective randomized trial. Diabetes Care 2003, 26, 1701-1705. [CrossRef]

47. Hart, C.E.; Loewen-Rodriguez, A.; Lessem, J. Dermagraft: Use in the Treatment of Chronic Wounds. Adv. Wound Care 2012, 1, 138-141. [CrossRef]

48. MacEwan, M.R.; MacEwan, S.R.; Kovacs, T.R.; Batts, J. What Makes the Optimal Wound Healing Material? A Review of Current Science and Introduction of a Synthetic Nanofabricated Wound Care Scaffold. Cureus 2017, 9, e1736. [CrossRef]

49. Naughton, G.; Mansbridge, J.; Gentzkow, G. A Metabolically Active Human Dermal Replacement for the Treatment of Diabetic Foot Ulcers. Artif. Organs 1997, 21, 1203-1210. [CrossRef] [PubMed]

50. Dermagraft: Use in the Treatment of Chronic Wounds-Google Scholar. Available online: https://scholar.google.com/scholar?hl= en\&as_sdt=0\%2C5\&q=Dermagraft \%3A+Use+in+the+Treatment+of+Chronic+Wounds\&btnG= (accessed on 28 December 2020).

51. Marston, W.A. Dermagraft ${ }^{\circledR}$, a bioengineered human dermal equivalent for the treatment of chronic nonhealing diabetic foot ulcer. Expert Rev. Med. Devices 2004, 1, 21-31. [CrossRef]

52. Omar, A.A.; Mavor, A.I.D.; Jones, A.M.; Homer-Vanniasinkam, S. Treatment of venous leg ulcers with Dermagraft ${ }^{\circledR}$. Eur. J. Vasc. Endovas. Surg. 2004, 27, 666-672. [CrossRef] [PubMed]

53. Gentzkow, G.D.; Iwasaki, S.D.; Hershon, K.S.; Mengel, M.; Prendergast, J.J.; Ricotta, J.J.; Lipkin, S. Use of dermagraft, a cultured human dermis, to treat diabetic foot ulcers. Diabetes Care 1996, 19, 350-354. [CrossRef]

54. Kumar, S.; Kang, H.J.; Berthiaume, F. Scaffolds for epidermal tissue engineering. In Handbook of Tissue Engineering Scaffolds; Woodhead Publishing: Cambridge, UK, 2019; Volume 2, pp. 173-191.

55. Curran, M.P.; Plosker, G.L. Bilayered Bioengineered Skin Substitute (Apligraf ${ }^{\circledR}$ ): A Review of Its Use in the Treatment of Venous Leg Ulcers and Diabetic Foot Ulcers. BioDrugs 2002, 16, 439-455. [CrossRef] [PubMed]

56. Eaglstein, W.H.; Alvarez, O.M.; Auletta, M.; Leffel, D.; Rogers, G.S.; Zitelli, J.A.; Norris, J.E.; Thomas, I.; Irondo, M.; Fewkes, J.; et al. Acute Excisional Wounds Treated with a Tissue-Engineered Skin (Apligraf). Dermatol. Surg. 1999, 25, 195-201. [CrossRef]

57. Foley, E.; Robinson, A.; Maloney, M. Skin Substitutes and Dermatology: A Review. Curr. Dermatol. Rep. 2013, 2, 101-112. [CrossRef]

58. Sibbald, R.G.; Zuker, R.; Coutts, P.; Coelho, S.; Williamson, D.; Queen, D. Using a dermal skin substitute in the treatment of chronic wounds secondary to recessive dystrophic epidermolysis bullosa: A case series. Ostomy Wound Manag. 2005, $51,22-46$.

59. Hasegawa, T.; Suga, Y.; Mizoguchi, M.; Ikeda, S.; Ogawa, H.; Kubo, K.; Matsui, H.; Kagawa, S.; Kuroyanagi, Y. Clinical trial of allogeneic cultured dermal substitute for the treatment of intractable skin ulcers in 3 patients with recessive dystrophic epidermolysis bullosa*. J. Am. Acad. Dermatol. 2004, 50, 803-804. [CrossRef]

60. Braziulis, E.; Biedermann, T.; Hartmann-Fritsch, F.; Schiestl, C.; Pontiggia, L.; Böttcher-Haberzeth, S.; Reichmann, E.; Meuli, M. Skingineering I: Engineering porcine dermo-epidermal skin analogues for autologous transplantation in a large animal model. Pediatr. Surg. Int. 2011, 27, 241-247. [CrossRef]

61. Still, J.; Glat, P.; Silverstein, P.; Griswold, J.; Mozingo, D. The use of a collagen sponge/living cell composite material to treat donor sites in burn patients. Burns 2003, 29, 837-841. [CrossRef]

62. Böttcher-Haberzeth, S.; Kapoor, S.; Meuli, M.; Neuhaus, K.; Biedermann, T.; Reichmann, E.; Schiestl, C. Osmotic expanders in children: No filling-No control-No problem? Eur. J. Pediatr. Surg. 2011, 21, 163-167. [CrossRef] [PubMed]

63. Schiestl, C.; Neuhaus, K.; Biedermann, T.; Böttcher-Haberzeth, S.; Reichmann, E.; Meuli, M. Novel Treatment for Massive Lower Extremity Avulsion Injuries in Children: Slow, but Effective with Good Cosmesis. Eur. J. Pediatr. Surg. 2010, 21, 106-110. [CrossRef]

64. Schiestl, C.; Stiefel, D.; Meuli, M. Giant naevus, giant excision, eleg (i) ant closure? Reconstructive surgery with Integra Artificial $\mathrm{Skin}^{\circledR}$ to treat giant congenital melanocytic naevi in children. J. Plast. Reconstr. Aesthet. Surg. 2010, 63, 610-615. [CrossRef] 
65. Klar, A.S.; Biedermann, T.; Michalak, K.; Michalczyk, T.; Meuli-Simmen, C.; Scherberich, A.; Meuli, M.; Reichmann, E. Human Adipose Mesenchymal Cells Inhibit Melanocyte Differentiation and the Pigmentation of Human Skin via Increased Expression of TGF- $\beta 1$. J. Invest. Dermatol. 2017, 137, 2560-2569. [CrossRef] [PubMed]

66. Klar, A.S.; Zimoch, J.; Biedermann, T. Skin Tissue Engineering: Application of Adipose-Derived Stem Cells. BioMed Res. Int. 2017, 2017, 1-12. [CrossRef]

67. Boyce, S.T.; Hansbrough, J.F. Biologic attachment, growth, and differentiation of cultured human epidermal keratinocytes on a graftable collagen and chondroitin-6-sulfate substrate. Surgery 1988, 103, 421-431.

68. Boyce, S.T.; Greenhalgh, D.G.; Kagan, R.J.; Housinger, T.; Sorrell, J.M.; Childress, C.P.; Rieman, M.; Warden, G.D. Skin Anatomy and Antigen Expression after Burn Wound Closure with Composite Grafts of Cultured Skin Cells and Biopolymers. Plast. Reconstr. Surg. 1993, 91, 632-641. [CrossRef] [PubMed]

69. Klar, A.S.; Michalak, K.; Böttcher-Haberzeth, S.; Reichmann, E.; Meuli, M.; Biedermann, T. The expression pattern of keratin 24 in tissue-engineered dermo-epidermal human skin substitutes in an in vivo model. Pediatr. Surg. Int. 2018, 34, 237-244. [CrossRef]

70. Hartmann-Fritsch, F.; Biedermann, T.; Braziulis, E.; Luginbuehl, J.; Pontiggia, L.; Böttcher-Haberzeth, S.; Van Kuppevelt, T.H.; Faraj, K.A.; Schiestl, C.; Meuli, M.; et al. Collagen hydrogels strengthened by biodegradable meshes are a basis for dermoepidermal skin grafts intended to reconstitute human skin in a one-step surgical intervention. J. Tissue Eng. Regen. Med. 2012, 10, 81-91. [CrossRef] [PubMed]

71. Braziulis, E.; Diezi, M.; Biedermann, T.; Pontiggia, L.; Schmucki, M.; Hartmann-Fritsch, F.; Luginbühl, J.; Schiestl, C.; Meuli, M.; Reichmann, E. Modified Plastic Compression of Collagen Hydrogels Provides an Ideal Matrix for Clinically Applicable Skin Substitutes. Tissue Eng. Part C Methods 2012, 18, 464-474. [CrossRef]

72. Kisiel, M.A.; Klar, A.S. Isolation and Culture of Human Dermal Fibroblasts. Methods Mol. Biol. 2019, 1993, 71-78. [CrossRef] [PubMed]

73. Klar, A.S.; Böttcher-Haberzeth, S.; Biedermann, T.; Kisiel, M.A.; Reichmann, E.; Meuli, M. Differential expression of granulocyte, macrophage, and hypoxia markers during early and late wound healing stages following transplantation of tissue-engineered skin substitutes of human origin. Pediatr. Surg. Int. 2014, 30, 1257-1264. [CrossRef]

74. Micka, K.; Biedermann, T.; Reichmann, E.; Meuli, M.; Klar, A.S. Induction of angiogenic and inflammation-associated dermal biomarkers following acute UVB exposure on bio-engineered pigmented dermo-epidermal skin substitutes in vivo. Pediatr. Surg. Int. 2019, 35, 129-136. [CrossRef]

75. Meuli, M.; Hartmann-Fritsch, F.; Hüging, M.; Marino, D.; Saglini, M.; Hynes, S.; Neuhaus, K.; Manuel, E.; Middelkoop, E.; Reichmann, E.; et al. A Cultured Autologous Dermo-epidermal Skin Substitute for Full-Thickness Skin Defects: A Phase I, Open, Prospective Clinical Trial in Children. Plast. Reconstr. Surg. 2019, 144, 188-198. [CrossRef] [PubMed]

76. Amirsadeghi, A.; Jafari, A.; Eggermont, L.J.; Hashemi, S.-S.; Bencherif, S.A.; Khorram, M. Vascularization strategies for skin tissue engineering. Biomater. Sci. 2020, 8, 4073-4094. [CrossRef] [PubMed]

77. Dehkordi, A.N.; Babaheydari, F.M.; Chehelgerdi, M.; Dehkordi, S.R. Skin tissue engineering: Wound healing based on stem-cellbased therapeutic strategies. Stem Cell Res. Ther. 2019, 10, 1-20. [CrossRef]

78. Nilforoushzadeh, M.A.; Sisakht, M.M.; Amirkhani, M.A.; Seifalian, A.M.; Banafshe, H.R.; Verdi, J.; Nouradini, M. Engineered skin graft with stromal vascular fraction cells encapsulated in fibrin-collagen hydrogel: A clinical study for diabetic wound healing. J. Tissue Eng. Regen. Med. 2020, 14, 424-440. [CrossRef]

79. Güven, S.; Mehrkens, A.; Saxer, F.; Schaefer, D.J.; Martinetti, R.; Martin, I.; Scherberich, A. Engineering of large osteogenic grafts with rapid engraftment capacity using mesenchymal and endothelial progenitors from human adipose tissue. Biomaterials 2011, 32, 5801-5809. [CrossRef]

80. Annabi, N.; Tamayol, A.; Uquillas, J.A.; Akbari, M.; Bertassoni, L.E.; Cha, C.; Camci-Unal, G.; Dokmeci, M.R.; Peppas, N.A.; Khademhosseini, A. 25th Anniversary Article: Rational Design and Applications of Hydrogels in Regenerative Medicine. Adv. Mater. 2013, 26, 85-124. [CrossRef]

81. Rana, D.; Kumar, T.S.; Ramalingam, M. Cell-laden hydrogels for tissue engineering. J. Biomater. Tissue Eng. 2014, 4, 507-535. [CrossRef]

82. Zimoch, J.; Padial, J.S.; Klar, A.S.; Vallmajo-Martin, Q.; Meuli, M.; Biedermann, T.; Wilson, C.J.; Rowan, A.; Reichmann, E. Polyisocyanopeptide hydrogels: A novel thermo-responsive hydrogel supporting pre-vascularization and the development of organotypic structures. Acta Biomater. 2018, 70, 129-139. [CrossRef]

83. Tavakoli, S.; Kharaziha, M.; Nemati, S.; Kalateh, A. Nanocomposite hydrogel based on carrageenan-coated starch/cellulose nanofibers as a hemorrhage control material. Carbohydr. Polym. 2021, 251, 117013. [CrossRef]

84. Tavakoli, S.; Kharaziha, M.; Kermanpur, A.; Mokhtari, H. Sprayable and injectable visible-light Kappa-carrageenan hydrogel for in-situ soft tissue engineering. Int. J. Biol. Macromol. 2019, 138, 590-601. [CrossRef] [PubMed]

85. Zhu, J.; Marchant, R.; Hu, J. Biomimetic hydrogels as scaffolds for tissue-engineering applications. In Biomimetic Biomaterials: Structure and Applications; Woodhead Publishing: Cambridge, UK, 2013; pp. 238-275. [CrossRef]

86. Kumacheva, E.; Prince, E. Design and applications of man-made biomimetic fibrillar hydrogels. Nat. Rev. Mater. 2019, 4, 99-115.

87. Pham, C.; Greenwood, J.; Cleland, H.; Woodruff, P.; Maddern, G. Bioengineered skin substitutes for the management of burns: A systematic review. Burns 2007, 33, 946-957. [CrossRef]

88. Kumar, R.J.; Kimble, R.M.; Boots, R.; Pegg, S.P. Treatment of partial-thickness burns: A prospective, randomized trial using TranscyteTM. ANZ J. Surg. 2004, 74, 622-626. [CrossRef] 
89. Sharma, Y.; Tiwari, A.; Hattori, S.; Terada, D.; Sharma, A.K.; Ramalingam, M.; Kobayashi, H. Fabrication of conducting electrospun nanofibers scaffold for three-dimensional cells culture. Int. J. Biol. Macromol. 2012, 51, 627-631. [CrossRef]

90. Mokhtari, H.; Kharaziha, M.; Karimzadeh, F.; Tavakoli, S. An injectable mechanically robust hydrogel of Kappa-carrageenandopamine functionalized graphene oxide for promoting cell growth. Carbohydr. Polym. 2019, 214, 234-249. [CrossRef]

91. El-Sherbiny, I.M.; Yacoub, M.H. Hydrogel scaffolds for tissue engineering: Progress and challenges. Glob. Cardiol. Sci. Pract. 2013, 2013, 316-342. [CrossRef]

92. Park, J.H.; Chung, B.G.; Lee, W.G.; Kim, J.; Brigham, M.D.; Shim, J.; Lee, S.; Hwang, C.M.; Durmus, N.G.; Demirci, U.; et al. Microporous cell-laden hydrogels for engineered tissue constructs. Biotechnol. Bioeng. 2010, 106, 138-148. [CrossRef] [PubMed]

93. Cordell, J.M.; Vogl, M.L.; Johnson, A.J.W. The influence of micropore size on the mechanical properties of bulk hydroxyapatite and hydroxyapatite scaffolds. J. Mech. Behav. Biomed. Mater. 2009, 2, 560-570. [CrossRef]

94. Li, Q.; Mai, Y.-W. Biomaterials for Implants and Scaffolds. In Biomaterials Science and Engineering; Springer: Berlin, Germany, 2017; Volume 8, ISBN 978-3-662-53572-1.

95. Klawitter, J.J.; Hulbert, S.F. Application of porous ceramics for the attachment of load bearing internal orthopedic applications. J. Biomed. Mater. Res. 1971, 5, 161-229. [CrossRef]

96. Yeh, J.; Blumling, J.; Karp, J.M.; Gantz, J.; Chandawarkar, A.; Eng, G.; Iii, J.B.; Langer, R.; Khademhosseini, A. Micromolding of shape-controlled, harvestable cell-laden hydrogels. Biomaterials 2006, 27, 5391-5398. [CrossRef] [PubMed]

97. Galperin, A.; Long, T.J.; Ratner, B.D. Degradable, Thermo-Sensitive Poly(N-isopropyl acrylamide)-Based Scaffolds with Controlled Porosity for Tissue Engineering Applications. Biomacromolecules 2010, 11, 2583-2592. [CrossRef]

98. Eke, G.; Mangir, N.; Hasirci, N.; MacNeil, S.; Hasirci, V. Development of a UV crosslinked biodegradable hydrogel containing adipose derived stem cells to promote vascularization for skin wounds and tissue engineering. Biomaterials 2017, 129, 188-198. [CrossRef]

99. Pereira, R.F.; Sousa, A.; Barrias, C.C.; Bayat, A.; Granja, P.L.; Bártolo, P. Advances in bioprinted cell-laden hydrogels for skin tissue engineering. Biomanuf. Rev. 2017, 2, 1. [CrossRef]

100. Murphy, S.V.; Atalaa, A. 3D bioprinting of tissues and organs. Nat. Biotechnol. 2014, 32, 773-785. [CrossRef]

101. El-Serafi, A.T.; El-Serafi, I.T.; Elmasry, M.; Sjöberg, F. Skin regeneration in three dimensions, current status, challenges and opportunities. Differentiation 2017, 96, 26-29. [CrossRef]

102. VijayaVenkataRaman, S.; Lu, W.F.; Fuh, J.Y.H. 3D bioprinting of skin: A state-of-the-art review on modelling, materials, and processes. Biofabrication 2016, 8, 032001. [CrossRef]

103. Yu, J.R.; Navarro, J.; Coburn, J.C.; Mahadik, B.; Molnar, J.; Iv, J.H.H.; Nam, A.J.; Fisher, P.J.P. Current and Future Perspectives on Skin Tissue Engineering: Key Features of Biomedical Research, Translational Assessment, and Clinical Application. Adv. Healtc. Mater. 2019, 8, e1801471. [CrossRef]

104. Li, H.; Tan, C.; Li, L. Review of 3D printable hydrogels and constructs. Mater. Des. 2018, 159, 20-38. [CrossRef]

105. Huang, G.; Li, F.; Zhao, X.; Ma, Y.; Li, Y.; Min, L.; Jin, G.; Lu, T.J.; Genin, G.M.; Xu, F. Functional and Biomimetic Materials for Engineering of the Three-Dimensional Cell Microenvironment. Chem. Rev. 2017, 117, 12764-12850. [CrossRef] [PubMed]

106. Cubo, N.; Garcia, M.; Del Cañizo, J.F.; Velasco, D.; Jorcano, J.L. 3D bioprinting of functional human skin: Production and in vivo analysis. Biofabrication 2016, 9, 015006. [CrossRef] [PubMed]

107. Yanez, M.; Rincon, J.; Dones, A.; De Maria, C.; Gonzales, R.; Boland, T. In Vivo Assessment of Printed Microvasculature in a Bilayer Skin Graft to Treat Full-Thickness Wounds. Tissue Eng. Part A 2015, 21, 224-233. [CrossRef]

108. Hakimi, N.; Cheng, R.; Leng, L.; Sotoudehfar, M.; Ba, P.Q.; Bakhtyar, N.; Amini-Nik, S.; Jeschke, M.G.; Günther, A. Handheld skin printer: In situ formation of planar biomaterials and tissues. Lab Chip 2018, 18, 1440-1451. [CrossRef]

109. Liu, P.; Shen, H.; Zhi, Y.; Si, J.; Shi, J.; Guo, L.; Shen, S.G. 3D bioprinting and in vitro study of bilayered membranous construct with human cells-laden alginate/gelatin composite hydrogels. Coll. Surf. B Biointerfaces 2019, 181, 1026-1034. [CrossRef]

110. Albanna, M.; Binder, K.W.; Murphy, S.V.; Kim, J.; Qasem, S.A.; Zhao, W.; Tan, J.; El-Amin, I.B.; Dice, D.D.; Marco, J.; et al. In Situ Bioprinting of Autologous Skin Cells Accelerates Wound Healing of Extensive Excisional Full-Thickness Wounds. Sci. Rep. 2019, 9,1-15. [CrossRef] [PubMed]

111. Hafezi, F.; Scoutaris, N.; Douroumis, D.; Boateng, J.S. 3D printed chitosan dressing crosslinked with genipin for potential healing of chronic wounds. Int. J. Pharm. 2019, 560, 406-415. [CrossRef]

112. Admane, P.; Gupta, A.C.; Jois, P.; Roy, S.; Lakshmanan, C.C.; Kalsi, G.; Bandyopadhyay, B.; Ghosh, S. Direct 3D bioprinted fullthickness skin constructs recapitulate regulatory signaling pathways and physiology of human skin. Bioprinting 2019, 15, e00051. [CrossRef]

113. Chinga-Carrasco, G.; Ehman, N.V.; Filgueira, D.; Johansson, J.; Vallejos, M.E.; Felissia, F.E.; Area, M.C. Bagasse-A major agro-industrial residue as potential resource for nanocellulose inks for 3D printing of wound dressing devices. Addit. Manuf. 2019, 28, 267-274. [CrossRef]

114. Intini, C.; Elviri, L.; Cabral, J.; Mros, S.; Bergonzi, C.; Bianchera, A.; Flammini, L.; Govoni, P.; Barocelli, E.; McConnell, M. 3D-printed chitosan-based scaffolds: An in vitro study of human skin cell growth and an in-vivo wound healing evaluation in experimental diabetes in rats. Carbohydr. Polym. 2018, 199, 593-602. [CrossRef] [PubMed] 
115. Seol, Y.J.; Lee, H.; Copus, J.S.; Kang, H.W.; Cho, D.W.; Atala, A.; Lee, S.J.; Yoo, J.J. 3D bioprinted biomask for facial skin reconstruction. Bioprinting 2018, 10, e00028. [CrossRef] [PubMed]

116. Si, H.; Xing, T.; Ding, Y.; Zhang, H.; Yin, R.; Zhang, W. 3D bioprinting of the sustained drug release wound dressing with double-crosslinked hyaluronic-acid-based hydrogels. Polymers 2019, 11, 1584. [CrossRef] [PubMed] 